\title{
ANALISIS UKURAN JENDELA HOTEL UNTUK MEMINIMALISIR PENGUNAAN ENERGI PADA BANGUNAN
}

\author{
Muhammad Fadly Saleh
}

\begin{abstract}
ABSTRAK
Penggunaan bahan bakar fosil sebagai sumber energi menjadi salah satu penyebab terjadinya pemanasan global. Bangunan merupakan pengguna energi yang besar. Penelitian ini bertujuan menganalisis ukuran jendela hotel utuk meminimalisir penggunaan energi dalam bangunan. Penelitian ini merupakan penelitian kuantitatif dengan metode observasi dan eksperimental. Objek penelitian adalah bangunan Hotel Four Points Makassar yang berlokasi di jalan Landak Baru, Kota Makassar. Observasi terhadap fisik bangunan berupa gambar perancangan dan kondisi di lokasi proyek bangunan. Eksperimen terhadap hasil observasi dengan menganalisis beberapa ukuran jendela dengan menggunakan simulasi energi program komputer eQuest. Setelah mengubah ukuran jendela bangunan Hotel Four Points Makassar, konsumsi energi bangunan pada lantai tipikal mengalami penurunan hingga 9,59\% dari konsumsi energi eksisting bangunan. Ukuran jendela yang digunakan adalah $10 \%$ dari luas dinding eksterior.
\end{abstract}

Kata kunci: penghematan energi, eQuest, simulasi energi, pemanasan global, jendela

\section{Abstract}

The use of fossil fuel becomes one of the cause of global warming. Buildings are massive energy users. This research aims to analyze the size of hotel windows to minimize energy use on buildings. This research is a quantitative research, using observation and experimental methods. The research object is the Four Points Hotel building, located in Jln. Landak Baru of Makassar City. Observation of the building's physique is conducted on the building plans and the conditions of the building's project location. The experiment of the observation results by analyzing some windows sizes using an energy simulation computer program called eQuest. After resizing the windows of Four Points Makassar building, the building energy consumption on the typical floor decreased up to $9.59 \%$ from the energy consumption of the existing building. The window size used is $10 \%$ of the exterior wall area

Key-words: energy-saving, eQuest, energy simulation, global warming, window

\section{PENDAHUUAN}

Isu global warming atau pemanasan global yang sejak beberapa dekade terakhir melanda dunia hingga saat ini telah menyebabkan berbagai dampak negatif. Perubahan iklim yang disebabkan oleh pemanasan global sangat mempengaruhi ekosistem semua makhluk hidup di bumi ini, termasuk manusia. Meningkatnya suhu bumi menyebabkan suhu di dalam ruangan bangunan juga meningkat. Yang menyebabkan kenyamanan termal di dalam ruangan akan lebih sulit di penuhi dengan penghawaan alami, terutama di tengah-tengah perkotaan. Energi yang dibutuhkan untuk menciptakan penghawaan buataan akan semakin meningkat dengan meningkatnya suhu di dalam bangunan.

Penyebab terbesar dari pemanasan global adalah konsumsi energi berbahan bakar fosil, dimana bangunan merupakan pengguna energi yang sangat besar. Maka sudah seharusnyalah bangunan lebih memperhatikan penggunaan/ konsumsi energinya guna mengurangi pemanasan global. Menurut Satwiko (2005), energi adalah kemampuan untuk mengerjakan sesuatu. Salah satu bentuk energi adalah listrik, yang saat ini menjadi jantung pergerakan kehidupan manusia. Energi listrik ini dapat diperoleh dari sumber energi lain, seperti: batu bara, minyak bumi, air, angin, cahaya matahari dan lain sebagainya.

Secara umum, metode penghematan energi terbagi atas dua, yaitu metode aktif dan metode pasif. Metode aktif berupa penggunaan alat atau pengaturan perilaku, sedangkan metode pasif merupakan bagian dari bangunan yang tidak bergerak yang didesain khusus untuk tujuan tertentu. Menurut Syahrizal dkk (2013), salah satu sumber panas luar yang masuk dan menjadi beban untuk pendingin adalah penambahan kalor radiasi matahari melalui benda transparan seperti kaca. Karena hal tersebut, perlakuan terhadap kaca eksterior bangunan harus mendapat perhatian lebih. Ada beberapa metode untuk mengurangi panas matahari yang masuk melalui jendela eksterior bangunan, salah satunya yaitu mengatur luas bukaan jendela. Soebarto (2005), menyatakan bahwa pada bangunan dengan ratio luasan kaca terhadap dinding (window 
to wall ratio/WWR $30 \%$, maka pengaruh pembayangan akan menurunkan $20 \%$ penggunaan energi, sementara pemakaian kaca ganda bisa menurunkan hingga 5\%.

Banyaknya bangunan-bangunan tinggi yang yang terbangun, khususnya di Makassar yang dalam tiga tahun terakhir pembangunan hotelnya meningkat, namun tidak terlalu memperhatikan penggunaan energinya. Sementara metode-metode penghematan energi yang dijelaskan pada berbagai referensi literature belum menjelaskan secara tepat bagaimana menerapkannya pada bangunan tinggi yang sifatnya komersil seperti hotel. Karena itulah, penelitian ini bertujuan menganalisis perubahan ukuran jendela untuk meminimalisir penggunaan energi pada bangunan, khususnya bangunan hotel.

\section{ISI PENELITIAN}

\subsection{Metode}

Penelitian ini dilakukan untuk menganalisis beberapa ukuran jendela eksterior bangunan agar mampu meminimalisir penggunaan energi di dalam bangunan. Penelitian ini dilakukan pada bangunan Hotel Four Points Makassar, yang terletak di jalan Landak Baru, Kota Makassar, Sulawesi Selatan, Indonesia. Penelitian ini hanya meneliti lantai tipikal (1 lantai) dari hotel ini.

Penelitian ini merupakan penelitian kuantitatif dengan metode observasi dan eksperimental. Observasi pada bangunan Hotel Four Points Makassar, fisik dan gambar pelaksanaan/ perencanaan bangunan. Metode eksperimental berupa simulasi energi menggunakan komputer dengan program eQuest.

a. Metode Pengumpulan Data

Metode pengambilan data pada penelitian ini dilakukan dengan empat tahap: (1) Pengambilan data fisik, yaitu: gambar kerja atau gambar desain bangunan, pengamatan langsung terhadap kondisi fisik dan lingkungan sekitar bangunan; (2) Menghitung besar konsumsi energi pada eksisting desain bangunan Hotel Four Points Makassar, khusunya pada lantai tipikalnya yang menjadi fokus penelitian dengan menggunakan program eQuest, (3) Menghitung konsumsi energi pada lantai tipikal bangunan Hotel Four Points Makassar, setelah dilakukan perubahan pada ukuran jendelanya.

Pengambilan data fisik diperlukan sebagai input data pada program eQuest, sehingga simulasi yang bekerja pada program eQuest sifatnya valid. Dan pengamatan lingkungan sekitar diperlukan untuk mengetahui apakah lingkungan sekitar akan mempengaruhi iklim dalam bangunan.

Penelitian ini membandingkan ukuran jendela eksisting dengan ukuran jendela yang diubah dengan berdasar pada ratio luasan kaca terhadap dinding (window to wall ratio/WWR), 10\%-50\% dari luas bidang dinding eksterior.

\section{b. Analisis Data}

Penggunaan energi pada lantai tipikal tanpa ada perubahan apapun (eksisting) akan dibandingkan dengan penggunaa energi setelah ukuran jendela diubah. Jika setelah ukuran jendela diubah dan menunjukkan penurunan penggunaan energi yang cukup signifkan, berarti ukuran jendela tersebut dapat digunakan untuk meminimalisir penggunaan energi pada bangunan.

\subsection{Hasil}

\subsubsection{Gambaran Umum Hotel Four Points Makassar}

Bangunan Hotel Four Point ini terdiri dari 17 lantai ditambah dengan lantai atap dan 1 lantai basement, yang terletak di Jalan Landak baru, Kota Makassar, Sulawesi Selatan, Indonesia. Lantai tipikal yang menjadi objek penelitian merupakan lantai 7 hotel ini, dimana sebagian besar ruangannya berfungsi sebagai kamar tamu.Sumber energi pada bangunan ini $100 \%$ bersumber dari listrik PLN. Adapun genset disiapkan hanya sebagai cadangan jika listrik dari PLN tiba-tiba mati. Sistem penghawaan $100 \%$ menggunakan sistem penghawaan buatan. Seluruh ruangan pada bangunan ini menggunakan sistem AC sentral, termasuk pada kamar tamunya. Sistem pencahayaan masih menerapkan sistem pencahayaan alami pada siang hari, dimana tiap kamar tamu akan memiliki jendela besar $(200 \mathrm{~cm}$ x $200 \mathrm{~cm})$ dan memiliki void di bagian tengah bangunan dengan atap skylight.

\subsubsection{Penghitungan beban energi pada jendela eksisting $(200 \mathrm{~cm}$ x $200 \mathrm{~cm}$ \\ Tabel 1. Hasil pengukuran energi pada} jendela eksisting

\begin{tabular}{|l|c|}
\hline \multicolumn{1}{|c|}{ Pengguna Energi } & $\begin{array}{c}\text { Pemakaian Energi/ } \\
\text { Tahun } \\
\text { (kWh x 1000) }\end{array}$ \\
\hline Pendingin ruangan & 252,60 \\
\hline Kipas ventilasi & 20,20 \\
\hline Pompa dan Aux & 5,11 \\
\hline Pencahayaan & 67,67 \\
\hline \multicolumn{1}{|c|}{ Total } & $\mathbf{3 4 5 , 5 8}$ \\
\hline
\end{tabular}

2.2.3 Penghitungan beban energi pada jendela dengan WWR $10 \%(126 \mathrm{~cm}$ x $92 \mathrm{~cm})$ Tabel 2. Hasil pengukuran energi pada jendela dengan WWR $10 \%$

\begin{tabular}{|l|c|}
\hline \multicolumn{1}{|c|}{ Pengguna Energi } & $\begin{array}{c}\text { Pemakaian } \\
\text { Energi/ Tahun } \\
\text { (kWh x 1000) }\end{array}$ \\
\hline Pendingin ruangan & 210,00 \\
\hline Kipas ventilasi & 19,61 \\
\hline Pompa dan Aux & 5,11 \\
\hline Pencahayaan & 77,14 \\
\hline \multicolumn{1}{|c|}{ Total } & $\mathbf{3 1 2 , 4 4}$ \\
\hline
\end{tabular}


2.2.4 Penghitungan beban energi pada jendela dengan WWR 20\% (179 cm x $130 \mathrm{~cm})$ Tabel 3. Hasil pengukuran energi pada jendela dengan WWR $20 \%$

\begin{tabular}{|l|c|}
\hline Pengguna Energi & $\begin{array}{l}\text { Pemakaian } \\
\text { Energi/ Tahun } \\
\text { (kWh x 1000) }\end{array}$ \\
\hline Pendingin ruangan & 226,74 \\
\hline Kipas ventilasi & 19,80 \\
\hline Pompa dan Aux & 5,11 \\
\hline Pencahayaan & 72,41 \\
\hline \multicolumn{1}{|c|}{ Total } & $\mathbf{3 2 4 , 0 6}$ \\
\hline
\end{tabular}

2.2.5 Penghitungan beban energi pada jendela dengan WWR 30\% $(219 \mathrm{~cm} \times 159 \mathrm{~cm})$ Tabel 4. Hasil pengukuran energi pada jendela dengan WWR $30 \%$

\begin{tabular}{|l|c|}
\hline Pengguna Energi & $\begin{array}{l}\text { Pemakaian } \\
\text { Energi/ Tahun } \\
\text { (kWh x 1000) }\end{array}$ \\
\hline Pendingin ruangan & 247,36 \\
\hline Kipas ventilasi & 20,10 \\
\hline Pompa dan Aux & 5,11 \\
\hline Pencahayaan & 68,34 \\
\hline \multicolumn{1}{|c|}{ Total } & $\mathbf{3 4 0 , 9}$ \\
\hline
\end{tabular}

2.2.6 Penghitungan beban energi pada jendela dengan WWR $40 \%(253 \mathrm{~cm} \times 183 \mathrm{~cm})$ Tabel 5. Hasil pengukuran energi pada jendela dengan WWR $40 \%$

\begin{tabular}{|l|c|}
\hline Pengguna Energi & $\begin{array}{c}\text { Pemakaian } \\
\text { Energi/ Tahun } \\
\text { (kWh x 1000) }\end{array}$ \\
\hline Pendingin ruangan & 259,90 \\
\hline Kipas ventilasi & 20,33 \\
\hline Pompa dan Aux & 5,11 \\
\hline Pencahayaan & 66,73 \\
\hline Total & $\mathbf{3 5 2 , 0 7}$ \\
\hline
\end{tabular}

2.2.7 Penghitungan beban energi pada jendela dengan WWR 50\% (283 cm x $205 \mathrm{~cm})$ Tabel 5. Hasil pengukuran energi pada jendela dengan WWR $50 \%$

\begin{tabular}{|l|c|}
\hline \multicolumn{1}{|c|}{ Pengguna Energi } & $\begin{array}{c}\text { Pemakaian } \\
\text { Energi/ Tahun } \\
\text { (kWh x 1000) }\end{array}$ \\
\hline Pendingin ruangan & 277,82 \\
\hline Kipas ventilasi & 20,60 \\
\hline Pompa dan Aux & 5,11 \\
\hline Pencahayaan & 64,76 \\
\hline \multicolumn{1}{|c|}{ Total } & $\mathbf{3 6 8 , 2 8}$ \\
\hline
\end{tabular}

2.2.8 Perbandingan beban energi, jendela eksisting dan perubahan ukuran jendela

Tabel 6. Hasil pengukuran energi pada jendela dengan WWR 50\%

\begin{tabular}{|l|c|c|}
\hline $\begin{array}{l}\text { Ukuran } \\
\text { jendela }\end{array}$ & $\begin{array}{c}\text { Pemakaian } \\
\text { Energi/ }\end{array}$ & $\begin{array}{c}\text { Selisih } \\
\text { dengan }\end{array}$ \\
\hline
\end{tabular}

\begin{tabular}{|l|c|c|}
\hline & $\begin{array}{c}\text { Tahun } \\
(\mathbf{k W h} \times \mathbf{1 0 0 0})\end{array}$ & $\begin{array}{c}\text { eksisting } \\
\mathbf{( \% )}\end{array}$ \\
\hline eksisting & 345,58 & - \\
\hline WWR 10\% & 312,44 & $-9,59$ \\
\hline WWR 20\% & 324,06 & $-6,23$ \\
\hline WWR 30\% & 340,9 & $-1,35$ \\
\hline WWR 40\% & 352,07 & 1,88 \\
\hline WWR 50\% & 368,28 & 6,57 \\
\hline
\end{tabular}

Hasil perhitungan besar konsumsi energi pada lantai tipikal Hotel Four Points Makassar setelah dilakukan perubahan ukuran pada jendela menunjukkan bahwa semakin kecil ukuran jendela maka akan semakin kecil konsumsi energi bangunan, seperti yang terlihat pada gambar 1 . Ukuran jendela yang hanya $10 \%$ dari luas bidang dinding eksterior atau $126 \mathrm{~cm}$ x $92 \mathrm{~cm}$ mampu mengurangi konsumsi energi sebesar $9,59 \%$ atau $33.140 \mathrm{kWh} /$ tahun, dari konsumsi energi sebesar $345.580 \mathrm{kWh} /$ tahun (eksisting) menjadi $312.440 \mathrm{kWh} /$ tahun.

\subsection{Pembahasan}

Penelitian ini menunjukkan bahwa panas matahari dari luar ruangan ke dalam bangunan khususnya yang masuk melalui jendela memiliki andil besar pada penggunaan energi, karena besarnya energi untuk penghawaan pada bangunan jauh lebih besar dari penggunaan energi untuk pencahayaan. Sehingga semakin kecil jendela tempat masuknya cahaya dan panas matahari, maka semakin kecil energi yang dibutuhkan/ digunakan oleh bangunan tersebut.

Hasil penelitian ini sejalan dengan Ariestadi dkk (2014), gedung di negara beriklim tropis termasuk Indonesia paling banyak menggunakan energi untuk sistem tata udara (45-70\%), sistem tata cahaya (10$20 \%)$, lift dan eskalator (2-7\%), serta alat-alat elektronik (2-10\%). Jadi bisa dikatakan bahwa penggunaan/ konsumsi terbesar energi pada bangunan adalah untuk penghawaan buatan/ sistem tata udara. Karena itu, metode untuk mengurangi penggunaan energi untuk penghawaan seharusnya lebih diutamakan jika dibandingkan dengan metode untuk mengurangi penggunaan energi untuk pencahayaan. Hal ini juga sejalan dengan hasil Santoso \& Antaryama (2005), yang menemukan bahwa peningkatan perolehan cahaya alami membawa pengaruh pada penurunan kebutuhan energi pencahayaan, namun peningkatan perolehan cahaya alami justru mendorong peningkatan penerimaan panas yang selanjutnya juga meningkatkan kebutuhan energi pendinginan. Lonjakan kebutuhan energi ini jauh lebih besar dibanding dengan kebutuhan energi pencahayaan.

Hasil penelitian ini juga senada dengan Lyons \& Associates (2008), yang menemukan bahwa WWR $10 \%$ merupakan ukuran jendela yang optimal. Dimana penelitian ini menunjukkan bahwa semakin kecil ukuran jendela semakin kecil beban energi untuk penghawaan dan semakin besar beban energi 
untuk pencahayaan. Namun, karena beban energi untuk penghawaan jauh lebih besar dari pada untuk pencahayaan, maka beban energi secara keseluruhan tetap menurun.

\section{KESIMPULAN}

Berdasarkan hasil penelitian dapat disimpulkan:

a. Semakin kecil ukuran jendela eksterior maka semakin kecil pula energi yang dibutuhkan/ digunakan oleh bangunan tersebut.

b. Semakin kecil ukuran jendela eksterior maka semakin besar energi untuk pencahayaan dan semakin kecil energi untuk penghawaan. Karena cahaya matahari membawa serta panas yang akan meningkatkan suhu di dalam ruangan.

c. Konsumsi energi untuk penghawaan buatan jauh lebih besar dari pada konsumsi energi untuk pencahayaan buatan, sehingga perlu lebih diutamakan penghematan energi untuk penghawaan buatan dibandingkan untuk pencahayaan buatan.

d. Ukuran jendela dengan WWR $10 \%$ merupakan ukuran jendela terbaik untuk meminimalisir penggunaan energi pada bangunan.

\section{DAFTAR PUSTAKA}

Ariestadi Dian., Alfianto Imam \& Sulton Mohammad. (2014). Kriteria Kinerja Energi Untuk Kenyamanan Termal Pada Bangunan Fasilitas Pendidikan Tinggi Di Indonesia: Analisis Dengan Metode Important Performance Analysis. Jurnal RUAS, Volume 12 No 1, ISSN 1693-3702.

Lyons Peter \& Associates. (2008). Report to Australian Building Codes Board on Optimum Window Size for Energy Efficiency: BCA Volume One

Santoso Anik Juniwati \& Antaryama I Gusti Ngurah. (2005). Konsekuensi Energi Akibat Pemakaian Bidang Kaca pada Bangunan Tinggi di Daerah Tropis Lembab. Dimensi teknik arsitektur Vol. 33: 70 - 75

Satwiko Prasasto. (2005). Arsitektur Sadar Energi. Yogyakarta: Penerbit ANDI

Soebarto Veronica I. dalam Santoso, Anik Juniwati \& Antaryama, I Gusti Ngurah. (2005). Konsekuensi Energi Akibat Pemakaian Bidang Kaca pada Bangunan Tinggi di Daerah Tropis Lembab. Dimensi teknik arsitektur Vol. 33: 70 - 75.

Syahrizal Iman., Panjaitan Seno \& Yandri. (2013). Analisis Konsumsi Energi Listrik pada Sistem Pengkondisian Udara Berdasarkan Variasi
Kondisi Ruangan: Studi Kasus Di Politeknik Terpikat Sambas. Jurnal ELKHA Vol.5 